\title{
Diurnal flight activity of African bees Apis mellifera adansonii in different seasons and zones of Ghana
}

\author{
J Woyke
}

FAO Representative, Accra and Technology Consultancy Center of the University, Kumasi, Ghana *

(Received 30 May 1991; accepted 8 December 1991)

Summary - The number of Apis mellifera adansonii worker bees returning to the hive during 5 min was counted every $0.5-1.0 \mathrm{~h}$ throughout the day. The investigations were conducted during the dry and rainy season in 3 zones of Ghana. The pattern of flight activity in different zones did not differ much within each season. However, it differed greatly between seasons. In the rainy dearth season, a single peak of foraging activity occurred during the morning. Two peaks of foraging activity occurred during the honey flow, winter dry season; one shortly after sunrise and the other shortly before sunset. The presence of the second evening peak is explained by nectar availability.

Ap/s mellifera adansonil / flight activity / tropical climate / Africa

\section{INTRODUCTION}

It is important to know the diurnal flight activity of honey bees in different areas and throughout the seasons. Some apiary operations should be conducted during high flight activity and others during low activity. Woyke (1989) found a high correlation between flight activity and stinging behavior of African bees.

The pattern of diurnal flight activity is generally cone-shaped, with a peak around noon. This was true for $A m$ ligustica, $A m$ caucasica, $A m$ scutellata and their hybrids in Brazil (Lengler, 1984), for A mellifera in India (Verma and Dulta, 1986). A $m$ ligustica in Korea (Lee et al,
1987) and Canada (Szabo, 1980) and for $A m$ litorea and $A m$ monticola in Kenya (Mbaya, 1985). According to Kerr et al (1970) the flight activity of Italian bees in Brazil was highest between 8.30 and $10.30 \mathrm{~h}$ and that of African bees and their hybrids between 14.30 and $15.30 \mathrm{~h}$. While Gary (1967) found a bell-shaped curve for flight activity of $\boldsymbol{A}$ mellifera in a temperate area, he found an U-shaped pattern of daily flight in an irrigated desert area. He explained this pattern by high temperature and low humidity. Silva and de Jong (1990) presented a 3-peak pattern of flight activity at 7,14 and $16 \mathrm{~h}$ for Africanized bees in Brazil. Fletcher (1978) reported a peak of foraging activity prior to $5 \mathrm{~h}$, at

\footnotetext{
- Present address: Agricultural University, Bee Division, SGGW, Nowoursynowska 166, 02-766 Warsaw, Poland
} 
first light as characteristic of the African bee $A$ m scutellata in Natal, South Africa.

In this study diurnal foraging activity of A mellifera adansonii in different areas and seasons was investigated.

\section{MATERIALS AND METHODS}

The investigations were conducted in 1986/ 1987 in 3 environmentally different zones of Ghana: the south coastal savanna zone in ACcra, the central deciduous forest zone in Kumasi and the northern dry savanna zone in Tamale. The investigations were conducted during the dry season (December-February) and the rainy season (June-July). The same bee colonies were observed during both seasons in 2 zones. Observations in Tamale were conducted only during the rainy season.

To determine foraging activity, the number of worker bees returning to the hive during a 5-min period was counted. Special preparatory exercise was made to count bees at their maximal flight activity of 1.0-2.5 thousand per $5 \mathrm{~min}$. Three persons counted simultaneously returning bees per 5 or per 10 , till all 3 results were similar. The counts were repeated every $1 \mathrm{~h}$ starting from 5.30 till $18.30 \mathrm{~h}$. However, at the time when rapid changes in flight activity occurred, returning foragers were counted every 15-30 min. Thus, approximately 30 counts per day were made. However, the curves in figures 4-10 are based on 13 data points, each plotted at the full hour. Some other data served to verify the full hour records, especially at the maximum flight. Other records are mentioned in the text. The counts were repeated over 10 different days. Numbers of workers returning with pollen loads within the 5-min periods were also determined in some cases.

At the full hour, temperature was recorded, and also relative humidity during the dry season. In Kumasi, the experimental bee colony No 4 was weighed at weekly intervals, as were 2 others. The amount of brood was measured every 3 weeks in 3 colonies, including the experimental one. In other localities, the amount of brood was judged by the number of combs occupied by the brood.

Hours of daily sunrise and sunset in Ghana were available to the author. The sun rose and set on June 21 at $5.56 \mathrm{~h}$ and $18.24 \mathrm{~h}$ and on December 21 at $6.20 \mathrm{~h}$ and $17.52 \mathrm{~h}$ respectively.

\section{RESULTS}

\section{Start and end of flight activity}

During the night worker bees form a small cluster outside the hive entrance (fig 1). In the summer rainy season (July) some bees start walking out of the cluster at 5.00-5.10 h, crawling on the front wall of the hive (fig 2). Some of the crawling bees take flight at $5.15 \mathrm{~h}$ ie $45 \mathrm{~min}$ before sunrise, when it is still dark. Returning bees do not fly directly to the entrance, but land on the front wall of the hive and then walk to the entrance (fig 3). Some bees even land on the edge of the roof. Returning foragers are guided to the entrance by fanning bees with released scent glands. In the meantime it begins to get a little lighter. It is possible to read written records at 5.30, approximately $30 \mathrm{~min}$ before sunrise. The cluster outside the entrance disintegrates by $5.45 \mathrm{~h}$, and the bees fly out and return to the hive directly from/to the entrance or alighting board. At $5.30-5.45 \mathrm{~h}$ returning bees become visible and it is possible to count them.

In the evening, sunset occurs about $18.25 \mathrm{~h}$. The bees cease flying at $18.35 \mathrm{~h}$. The latest bees land on the front wall of the hive and walk to the entrances. At this time, the bees start to form a cluster outside the entrance. It is difficult to read written records at $18.45 \mathrm{~h}$, and by $18.55 \mathrm{~h}$ it is too dark to read.

In the winter dry season (DecemberFebruary), all the phenomena occurred about 15 min later in the morning and about 15 min earlier in the evening.

One can assume that in the darkness or low light intensity, the bees are not able to 


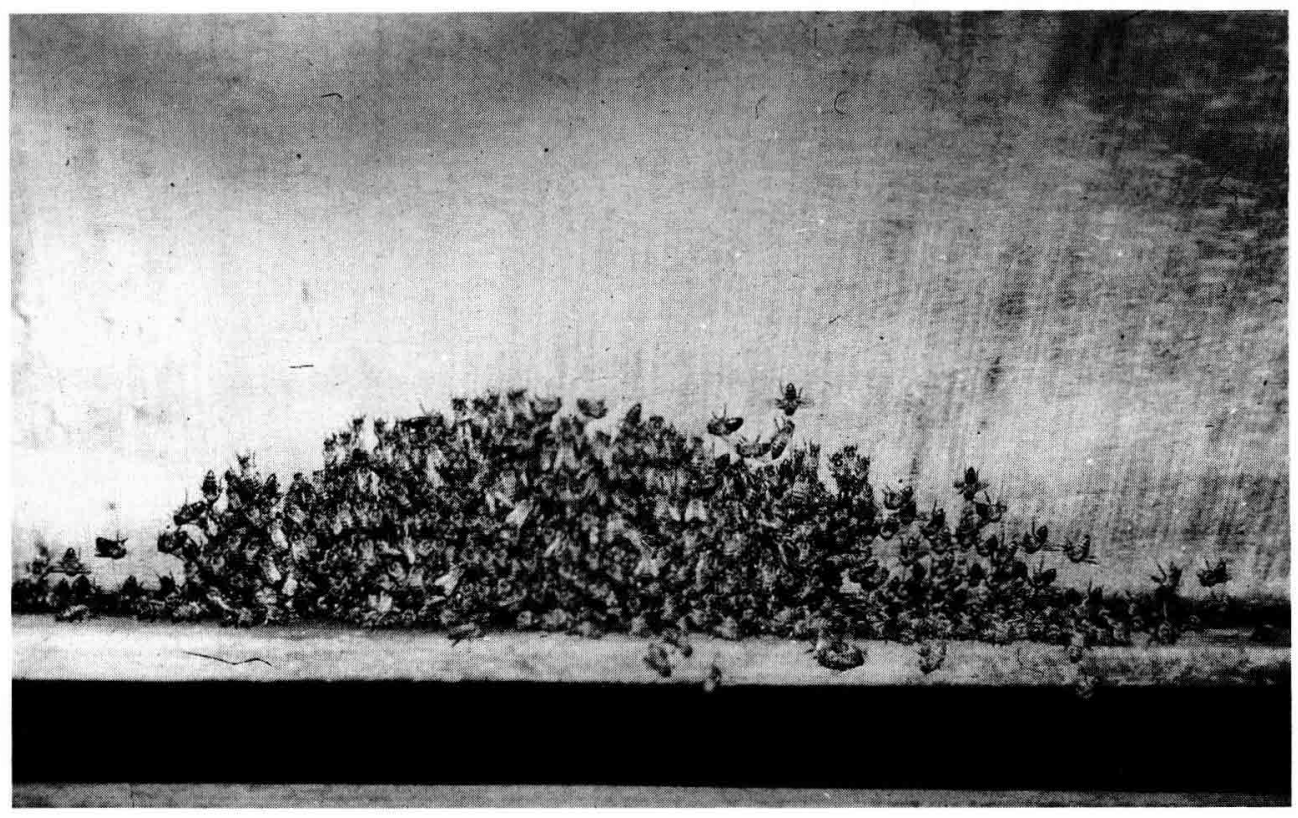

Fig 1. Bees clustering at night in front of the hive entrance.

land or start the flight directly to/from the entrance.

\section{Orientation flight}

Orientation flight of different colonies was recorded 20 times in different localities. Worker bees started this flight between 15 and $16 \mathrm{~h}$, and most frequently at $15 \mathrm{~h}$. In most cases, the flight lasted about $30 \mathrm{~min}$. At this time, the drones also started to fly. They continued their flights till $17 \mathrm{~h}$.

\section{Summer rainy dearth season}

During the summer rainy season, the sky is mostly cloudy, and frequent rains occur.
Therefore the temperature is not very high. During the investigation period, ie June and July, the temperature was very similar in all 3 localities: at $6 \mathrm{~h} 22-23^{\circ} \mathrm{C}$, at $12-14$ $\mathrm{h}$ it rose to $29.5-30.5^{\circ} \mathrm{C}$, and at $18 \mathrm{~h}$ it dropped to $26-28^{\circ} \mathrm{C}$ (fig 4). The amplitude between the lowest and highest temperature was about $7^{\circ} \mathrm{C}$.

The summer rainy season is the dearth period for the bees. Very few plants are flowering. The bees had to eat their honey reserves to fulfill their energetic needs. During the investigation period, bee colonies lost 1-2 kg of their total weight per week. The workers collected pollen from Zea mais and brought home enormously large pollen loads. This protein source enabled brood rearing to be maintained. On June 5, 1986, 15 combs were present in colony No 4 in 


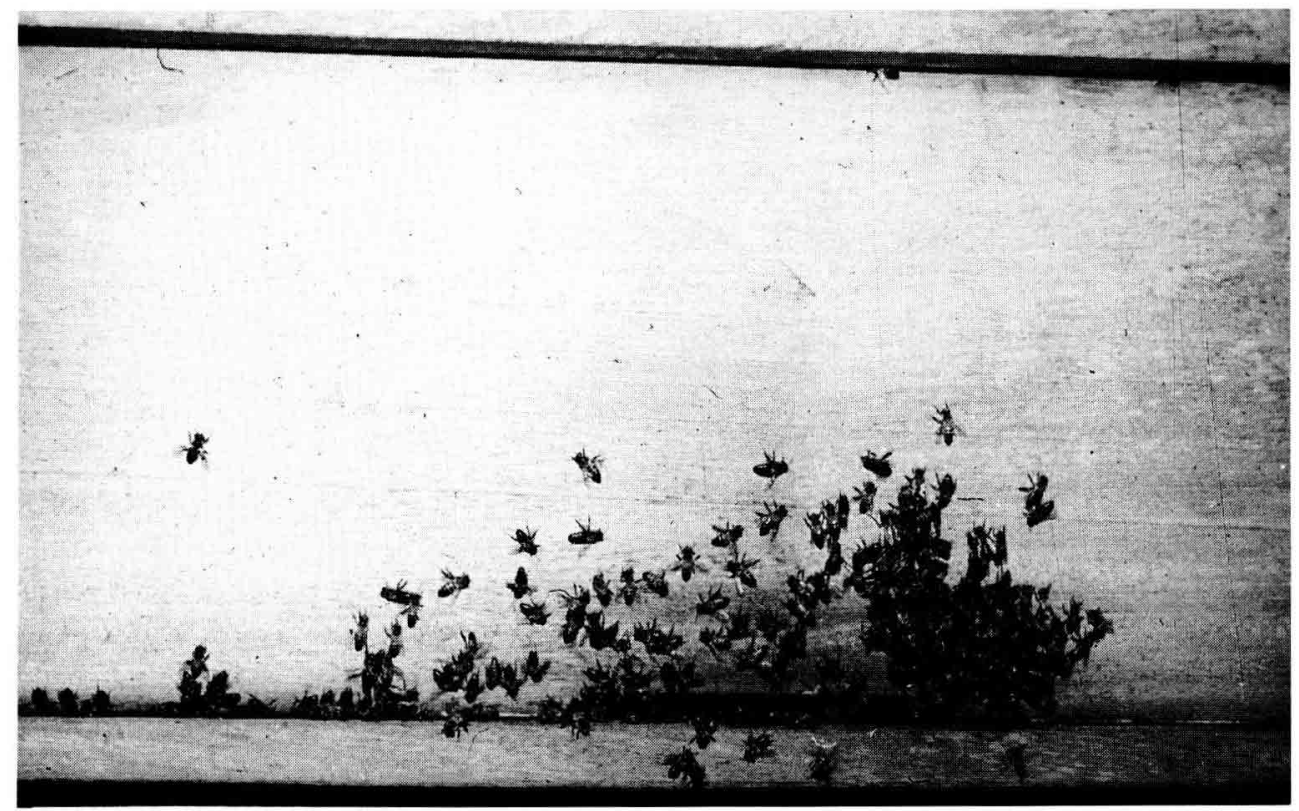

Fig 2. Partly dispersed cluster early in the morning. Returning bees land on the front wall of the hive.

Kumasi. Brood occupied 34700 cells in 10 combs, and on June 26, 39900 cells also in 10 combs. However, on July 17 , the amount of brood dropped to 17300 cells in 8 combs. Colonies investigated in Tamale and Accra were of similar strength.

The patterns of flight activity for 2 consecutive days, 12 and 13 June, were very similar in Kumasi. Therefore averages for both days are presented in figure 5 . On those days, it was possible to start counting flying workers at $5.30 \mathrm{~h}$, approximately $23 \mathrm{~min}$ before sunrise. At this time 745 workers $/ 5 \mathrm{~min}$ returned to the hive (not indicated in figure 5). The highest activity of 2400 workers $/ 5 \mathrm{~min}$ occurred at $6.00 \mathrm{~h}$, just at sunrise. Later, foraging activity decreased quite rapidly and by $11.0 \mathrm{~h}$ the rate dropped to 550 workers/5 min returning to the hive. Decreasing activity continued practically till the end of the day. Some higher activity was noticed between 15.3016.30 , when an orientation flight took place. At $18.00 \mathrm{~h}, 340$ workers $/ 5 \mathrm{~min}$ returned to the hive. The last count could be made at $18.30 \mathrm{~h}, 8 \mathrm{~min}$ after sunset, when 35 workers $/ 5$ min returned.

Eleven days later, patterns of flight activities on 2 consecutive days, June 23 and 24 , were also similar to each other. On both days, with the exception of the morning peak at $6.00 \mathrm{~h}$ (average 750 workers $/ 5$ $\mathrm{min})$, a higher peak of an average of 1163 workers $/ 5$ min was noticed at $9.00 \mathrm{~h}$ (fig 6). Afterwards, foraging decreased until the evening. 


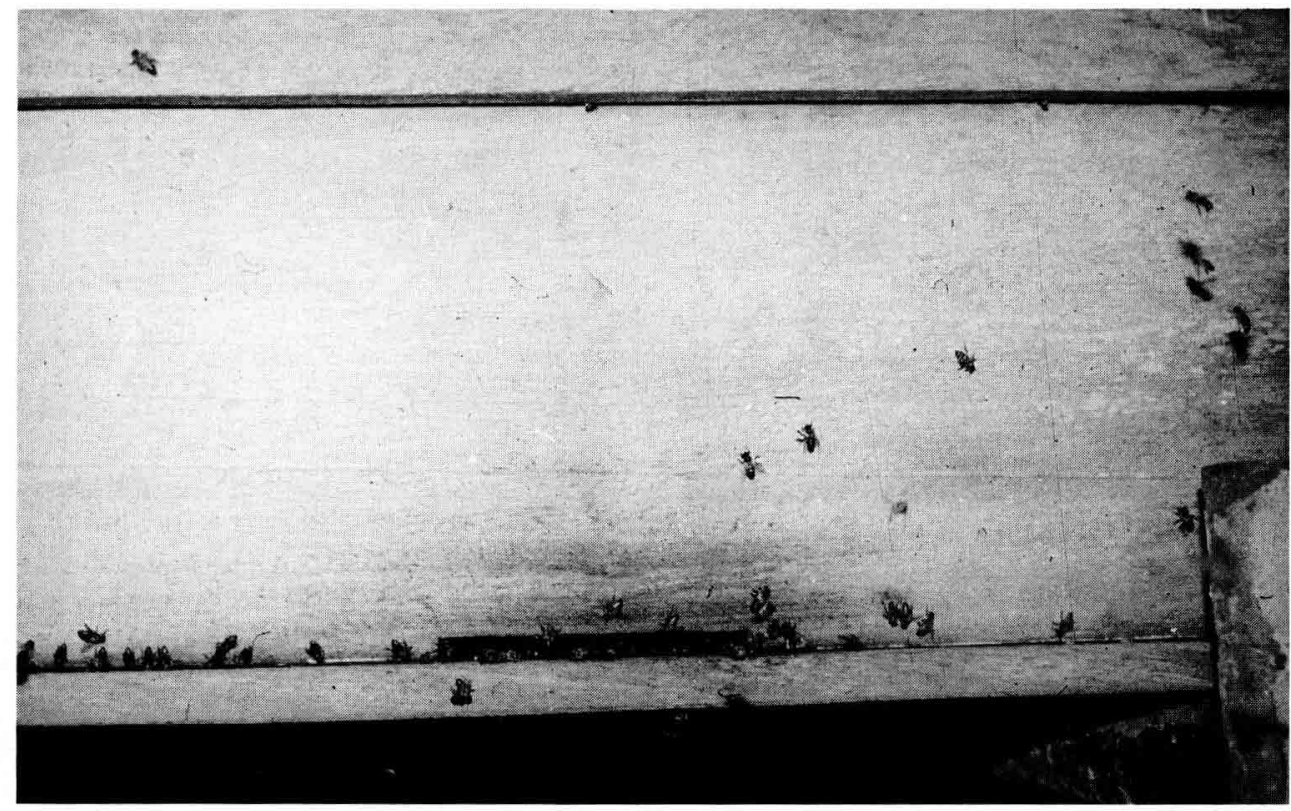

Fig 3. Early in the morning, following disappearance of the cluster, returning bees still land on the front wall of the hive, and some even on the edge of the roof.

Ten days later, the early morning peak at $6.00 \mathrm{~h}$ was no longer present in the northern savanna zone in Tamale, when only 270 workers $/ 5$ min returned to the hive (fig 7). The highest activity of 950 workers $/ 5 \mathrm{~min}$ had moved to $9.00 \mathrm{~h}$, similar to that observed earlier in Kumasi. Low activity of about 200 workers $/ 5$ min continued from 11.30 till the evening. The $16.00 \mathrm{~h}$ count was not conducted because an orientation flight occurred between 15.30 and $16.00 \mathrm{~h}$, and it was impossible to count the workers during the irregular flights.

About 1 month later (July, 22), in the coastal savanna zone in Accra, the highest activity of 2400 workers $/ 5$ min took place at sunrise, at $6.02 \mathrm{~h}$. This number was re- duced to 465 workers $/ 5$ min only $1 \mathrm{~h}$ later (fig 8). Some increase (750 workers/5 min) was noticed at $9.00 \mathrm{~h}$, but generally low variable activity continued till the end of the day. The lowest activity occurred between $14.00-16.00 \mathrm{~h}$, and again a slight increase of 500-645 workers $/ 5$ min was noticed between 17.00-18.00 h, $30 \mathrm{~min}$ before sunset. At sunset at $18.26 \mathrm{~h}, 290$ workers $/ 5$ min returned, and flight stopped by $18.35 \mathrm{~h}$.

\section{Winter dry honey flow season}

During the winter dry season, investigations were conducted in 2 localities only: at Kumasi and Accra. The temperature (fig 4) 


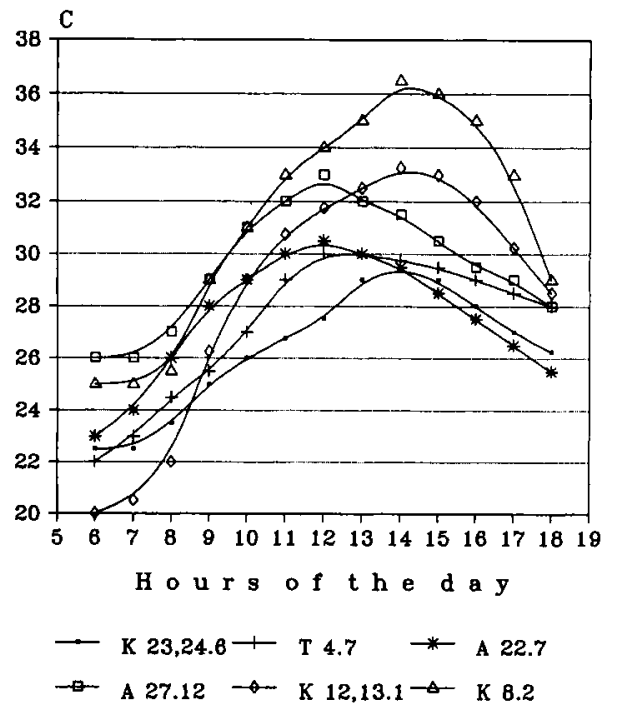

Fig 4. Temperature on some days during which investigations were conducted ( $\mathrm{K}=$ Kumasi, $\mathrm{T}=$ Tamale, $A=$ Accra, 22, 23.6 and 12, 13.1 = averages for both days).

and $\mathrm{RH}$ differed in each place. In January, the temperature in Kumasi at $6 \mathrm{~h}$ dropped to $20^{\circ} \mathrm{C}$, and was the lowest during the whole investigation period. At 12-14 $\mathrm{h}$ the temperature rose in both places to $33^{\circ} \mathrm{C}$, and dropped in the evening to $28-28.5^{\circ} \mathrm{C}$. In the deciduous forest zone in Kumasi the amplitude was much higher $\left(13^{\circ} \mathrm{C}\right)$ than near the ocean in Accra ( $\left.7^{\circ} \mathrm{C}\right)$. Later on in the season, the temperature at $14 \mathrm{~h}$ rose in February to $36.5^{\circ} \mathrm{C}$. $\mathrm{RH}$ in Accra, on Dec 27 was $100 \%$ at $6 \mathrm{~h}$; it dropped to $64 \%$ at $13 \mathrm{~h}$ and rose to $91 \%$ at $18 \mathrm{~h}$. In Kumasi, RH in January and February was also $100 \%$ at $6 \mathrm{~h}$. Sometimes, during the cool wind, the harmattan, the humidity condensed into fog, and water dropped from the leaves. At $13 \mathrm{~h} \mathrm{RH}$ dropped to $45-58 \%$, and at $18 \mathrm{~h}$ it rose to $52-60 \%$.

The winter dry season is the honey flow period. The nectar flow starts in October,

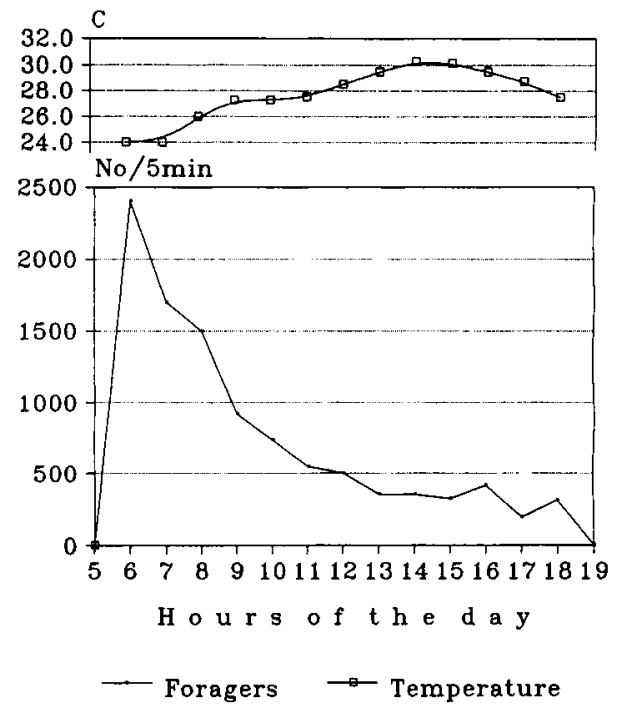

Fig 5. Single early morning peak in the diurnal flight activity of worker honeybees during the summer rainy season dearth in the central deciduous forest zone in Kumasi, No of foragers returning to the hive for $5 \mathrm{~min}$, mean for June 12 and $13,1986$.

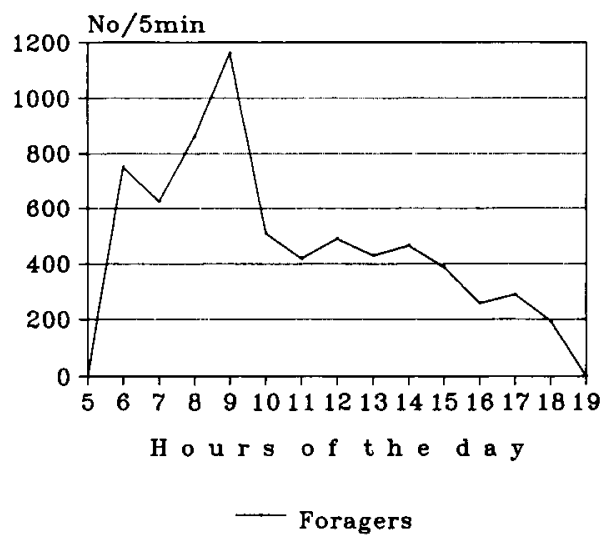

Fig 6. Shift in morning foraging peak to $9 \mathrm{~h}$ during the prolonged rainy season dearth in central deciduous forest zone in Kumasi, mean for June 23 and 24, 1986. 


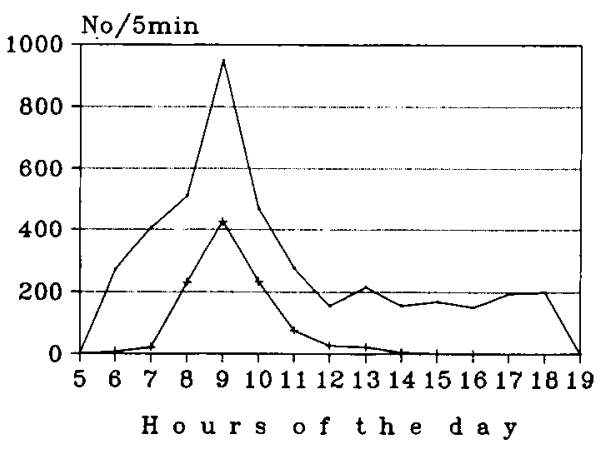

$\longrightarrow$ All foragers $\longrightarrow$ Pollen foragers

Fig 7. Single peak of foraging activity at $9 \mathrm{~h}$ during the rainy season dearth in the northern dry savanna zone in Tamale, July 4, 1986.

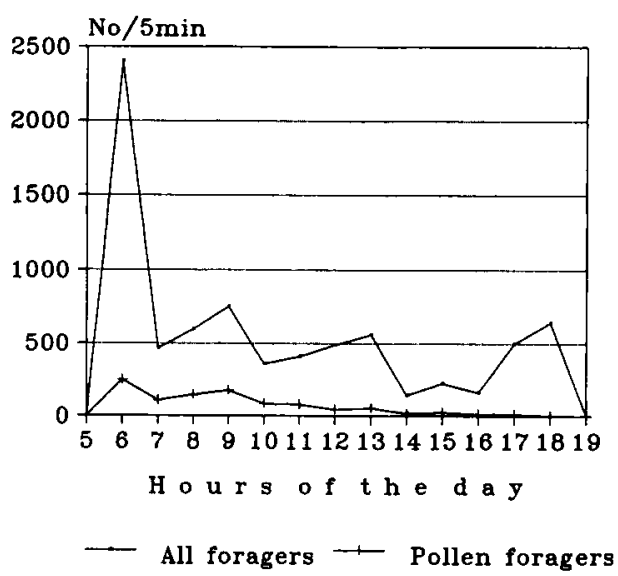

Fig 8. Single early morning peak of foraging activity during the rainy season dearth in the south coastal savanna zone in Accra, July 22, 1986.

when bee colonies may even gain $5 \mathrm{~kg}$ per week. During the investigation period in Accra (December), Neem tree Azadirachta indica was one of the most important hon-

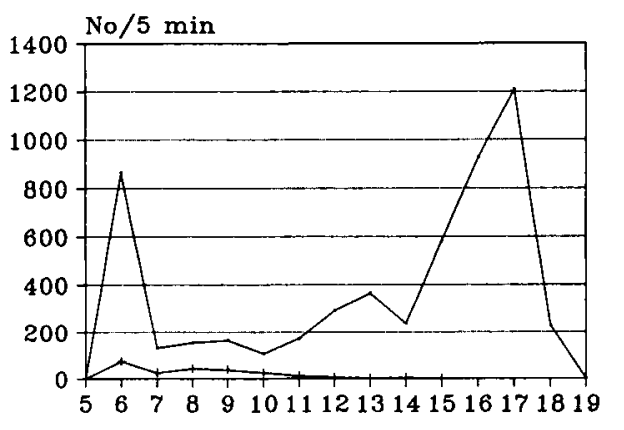

Hours of the da $y$

\section{All foragers — Pollen foragers}

Fig 9. Two peaks of foraging activity; one in the early morning and one late evening, during the winter dry season honey flow in the south coastal savanna zone in Accra, December, 27, 1986.

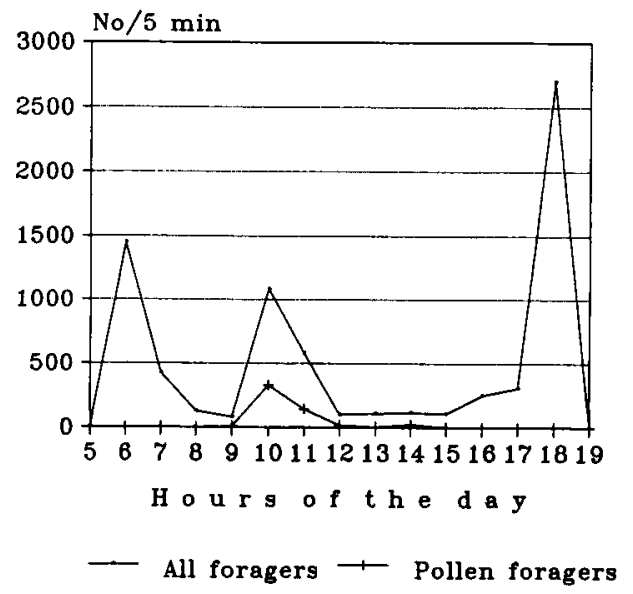

Fig 10. Three peaks of foraging activity during the dry season honey flow in the central deciduous forest zone in Kumasi, average for January 12 and $13,1987$.

ey plants, as was kapok Ceiba pentandra in Kumasi (January). During the flight investigation period, bee colonies gained in Kumasi 1-2 kg per week. In Kumasi, 8 


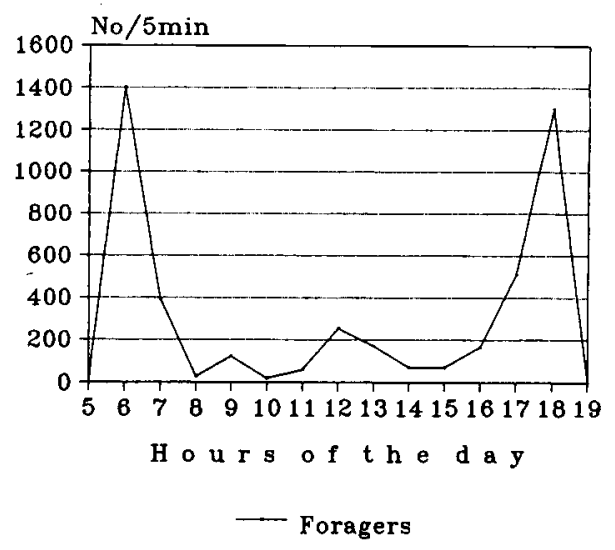

Fig 11. Two peaks of foraging activity during winter dry season honey flow in the central deciduous forest zone in Kumasi, February 8, 1987.

brood combs were found in colony No 4, in the 3-week check intervals from Dec 4 to Jan 15 and 7 combs on Feb 5. A similar number of brood combs was found in other colonies. It should be noted that the colonies were weaker in the second half of the honey flow period than in the dearth period in June.

It was possible to start counting bees returning to the hive in Accra during the winter season (Dec 27) at $5.50 \mathrm{~h}$ when 236 workers $/ 5$ min returned (fig 9). The morning peak of 865 workers $/ 5 \mathrm{~min}$ occurred at $6.15 \mathrm{~h}, 10 \mathrm{~min}$ before sunrise. Flight activity decreased rapidly till $7 \mathrm{~h}$, when only 134 workers $/ 5$ min returned. Low flight activity continued till $14 \mathrm{~h}$. Afternoon flight activity started to increase at $15.00 \mathrm{~h}$ and reached a peak of 1210 workers $/ 5 \mathrm{~min}$ at $17.00 \mathrm{~h}$. It was already getting dark at sunset, at $18.00 \mathrm{~h}$, when only 230 workers $/ 5$ min landed on the front wall of the hive. By $18.20 \mathrm{~h}$ the cluster outside the entrance had formed and only 12 workers $/ 5$ min landed on the front wall of the hive.

Two weeks later, the patterns of flight activity for 2 consecutive days, Jan 12 and 13 were similar in Kumasi. The averages (fig 10) show that the morning peak of 1450 workers/5 $\mathrm{min}$ also occurred at $6.15 \mathrm{~h}$. At $9.00 \mathrm{~h}$ flight activity almost stopped. However, $1 \mathrm{~h}$ later a peak of 1082 workers $/ 5$ min was noticed. Low activity continued throughout the day. The afternoon flight activity started to increase at $17.00 \mathrm{~h}$ and reached a high peak of 2700 workers $/ 5 \mathrm{~min}$ at sunset time, at $18.00 \mathrm{~h}$. Flight stopped at $18.30 \mathrm{~h}$, about $30 \mathrm{~min}$ after sunset. It was too dark to read by $18.35 \mathrm{~h}$. About 1 month later ( $8 \mathrm{Feb}$ ), the highest morning flight activity of 1400 workers $/ 5 \mathrm{~min}$ again occurred at $6.15 \mathrm{~h}$ (fig 11). Between $8.00-16.00 \mathrm{~h}$ foraging activity was low: $20-300$ workers $/ 5 \mathrm{~min}$. An afternoon peak of 1300 workers $/ 5$ min occurred at $18.00 \mathrm{~h}$, at sunset.

At the end of December and beginning of January, the evening peaks of flight activity in both places (Accra and Kumasi) were much higher than the morning ones (figs 9,10 ). One month later, the morning peak was higher than the evening one (fig 11). Later on in the season the morning peak increased up to 2400 workers $/ 5 \mathrm{~min}$ and the evening one disappeared during the rainy season (fig 5 ).

\section{DISCUSSION}

This study constitutes the first report of the pattern of honeybee flight activity in different zones of the same country. Both Gary (1967) and Fletcher (1978) reported flight activity at dawn and dusk. However, the phenomenon that bees start to fly and land in low light intensity not from/to the entrance but from/to the front wall of the hive was previously unknown. Compared to the 
most frequent cone- or bell-shaped pattern of flight activity reported for different European and African bee races (Lengler, 1984; Mbaya, 1985; Lee et al, 1987; Verma and Dulta, 1986, 1988), or Africanized bees in Brazil (Kerr et al, 1970) the pattern of flight activity of $A m$ adansonii in Ghana was different. The dry season pattern with the early morning and the evening peaks was similar to that described by Gary (1967) for A m ligustica in irrigated desert. This suggests that flight activity may sometimes depend more on the environmental conditions than on the race of the bees. Nevertheless, different patterns of flight activity have been recorded for different bee races foraging in the same conditions (Kerr et al, 1970). Only one early morning peak of flight activity at $6 \mathrm{~h}$ was not recorded before the present study.

\section{CONCLUSIONS}

The pattern of flight activity in very different zones but in the same season did not differ much. However, the pattern differed greatly during different seasons. Only an early morning peak occurred during the rainy dearth period at the beginning of the summer rainy season. Ten days later, the morning peak had shifted to $9.00 \mathrm{~h}$. This occurred in the deciduous forest zone as well as in the northern savanna zone. Probably the bees learned that the nectar remained available later in the day in the rainy season compared to the dry season. Two peaks of foraging activity, one early in the morning and the other late in the evening occurred during the honey flow winter dry season. The evening peak of flight activity was highest at the beginning of the season, and one month later the morning peak was higher. Probably, with the progress of the dry season, more nectar was available in the morning than in the evening, due to drying during the day. For- aging activity during midday, at the warm period of the day was always low.

One can propose the following hypothesis. African honey bees start searching for nectar early in the morning. This results in the early morning peak. Prolonged rainy season delays the morning peak. When little or no nectar is available, low foraging activity continues till the evening. During the dry honey flow season, low foraging occurs during the hot period of the day. However, in the evening, when the temperature is lower and the humidity higher, another peak of foraging activity occurs at sunset.

Résumé - Activité de vol diurne de l'abeille africaine, Apis mellifera adansonii, au Ghana en diverses régions et à diverses saisons. II est important de connaître l'activité de vol diurne des abeilles en divers lieux et diverses saisons. Certains travaux apicoles doivent être effectués lorsque l'activité de vol est élevée, d'autres lorsqu'elle est faible. Une forte corrélation a été trouvée entre l'activité de vol et la propension à piquer des abeilles africaines (Woyke, 1989). Les recherches ont été faites au Ghana dans 3 zones différentes : la savane de la côte Sud à Accra, la forêt de feuillus dans le Centre à Kumasi et la savane sèche du Nord à Tamale, pendant la saison sèche (décembre-février), période de miellées, et pendant la saison des pluies (juin-juillet), dépourvue de miellées. On a déterminé l'activité de vol en comptant durant $5 \mathrm{~min}$ le nombre d'ouvrières rentrant à la ruche à des intervalles de 30-60 min pendant $10 \mathrm{j}$.

Tôt le matin et tard le soir les ouvrières quittent la ruche, pas par le trou de vol mais par la paroi arrière. Pour une même saison l'activité de vol n'a pas beaucoup varié d'une région à l'autre. Par contre, la différence entre les saisons a été nette. Un 
seul pic à $6 \mathrm{~h}$ est observé pendant la période de disette au début de la saison des pluies (fig 5). Dix jours plus tard, le pic d'activité matinale s'est déplacé à $9 \mathrm{~h}$ (fig 6), que ce soit en forêt de feuillus ou dans la savane du Nord (fig 7). Les abeilles ont vraisemblablement appris que, pendant la saison des pluies, le nectar ne sèche pas aussi vite que durant la saison sèche. En hiver, période sèche et de miellées, l'activité de butinage présente 2 pics. L'un a lieu peu de temps après le lever du soleil, entre $6 \mathrm{~h}$ et $6 \mathrm{~h} \mathrm{15}$, l'autre peu de temps avant le coucher, entre $17 \mathrm{~h}$ et $18 \mathrm{~h}$ (fig 9 ). Au début de la saison sèche, le pic du soir est le plus fort (fig 10), alors qu'un mois plus tard c'est le pic du matin (fig 11). II est probable qu'il y a plus de nectar disponible le matin que le soir en raison du dessèchement au cours de la journée.

\section{Apis mellifera adansonii / activité de vol / climat tropical / Afrique}

\section{Zusammenfassung - Die tägliche Flug-} aktivität der afrikanischen Honigbienen, Apis mellifera adansonii, zu verschiedenen Jahreszeiten und in verschiedenen Zonen von Ghana. Es ist wichtig, die tägliche Flugaktivität der Honigbienen in unterschiedlichen Gebieten während der gesamten Saison zu kennen. Manche imkerliche Eingriffe sollten zur Zeit hoher Aktivität und andere während geringer Aktivität erfolgen. Woyke (1989) stellte eine enge Korrelation zwischen Flugaktivität und Stechverhalten bei Afrikanischen Bienen fest. Die Untersuchungen wurden in drei verschiedenen Zonen von Ghana durchgeführt: südliche Savannenzone an der Küste bei Accra; zentrale Laubwaldzone in Kumasi; nördliche Trockensavanne in Tamale. Die Beobachtungen wurden sowohl während der trockenen Trachtperiode (Dezember-Februar) wie in der trachtlosen Regenzeit (Juni-Juli) durchge- führt. Um die Flugaktivität zu erfassen, wurde die Zahl der zum Volk heimkehrenden Flugbienen an zehn verschiedenen Tagen den ganzen Tag über in Intervallen von 30-60 Minuten fünf Minuten lang gezählt. Am frühen Morgen und späten Abend fliegen die Bienen nicht vom Flugloch aus, sondern von der Stirnwand des Bienenstockes. Das Muster der Flugaktivität in den verschiedenen Zonen war während derselben Jahreszeit kaum verschieden. Zwischen den Jahreszeiten hingegen gab es deutliche Unterschiede. Während der trachtlosen Zeit zu Beginn der sommerlichen Regenzeit gab es nur einen einzigen Gipfel um 6.00 h (Abb 5). Zehn Tage später war der Morgengipfel der Trachtaktivität auf $9.00 \mathrm{~h}$ verschoben (Abb 6). Dies fand sowohl in der Laubwaldzone wie auch in der nördlichen Savannenzone statt (Abb 7). Wahrscheinlich lernten die Bienen, daß der Nektar während der Regenzeit nicht so schnell vertrocknet wie während der Trockenzeit. Zwei Gipfel von Trachtflügen waren während der Tracht in der winterlichen Trockenzeit zu beobachten. Einer fand gleich nach Sonnenaufgang, zwischen 6.00-6.15 h statt, der andere kurz vor Sonnenuntergang zwischen 17.00$18.00 \mathrm{~h}$ (Abb 9). Zu Beginn der Trockenzeit war der Abendgipfel der Flugaktivität am höchsten (Abb 10), aber einen Monat später war der Morgengipfel höher (Abb 11). Wahrscheinlich war am Morgen wegen des Austrocknens tagsüber mehr Nektar vorhanden als am Abend.

\section{Apis mellifera adansonii / Flugaktivität / Tropenklima / Afrika}

\section{REFERENCES}

Fletcher DJ (1978) The African bee, Apis mellifera adansonii, in Africa. Annu Rev Entomol 23, 151-171 
Gary NE (1967) Diurnal variations in the intensity of flight activity from honeybee colonies. $J$ Apic Res 6, 65-68

Kerr EW, Goncalves LS, Blotta LF, Maciel HB (1970) Biologia comparada entre as abelhas Italianas (Apis mellifera ligustica) Africanas (Apis mellifera adansonii) e suas hibridas. I Congr Brasil Apicult, Florianopolis, 151-185

Lee ML, Choi SY, Cho YH (1987) Diurnal activity of honeybees (Apis mellifera) at the hive entrance. Korean J Apic 2, 27-42 (in Korean)

Lengler $S$ (1984) Compartamento de linhagens de abelhas (Apis mellifera) quanto a sua actividade de voo. Cien Cult 39, 1606-1608

Mbaya JSK (1985) The distribution of African honeybees in Kenya and some aspects of their behaviour. Proc 3rd Int Conf Apic Trop Climates, Nairobi. Int Bee Res Assoc, 56-60

Silva M, De Jong D (1990) Diurnal flight activity of Africanized and European honey bees. Apiacta 25, 78-80

Szabo TJ (1980) Effect of weather factors on honeybee flight activity and colony weight gain. J Apic Res 19, 164-171

Verma LR, Dulta PC (1986) Foraging behaviour of Apis cerana indica and Apis mellifera in pollinating apple flowers. J Apic Res 25, 197 201

Woyke J (1989) Biology and management of African honeybees (Apis mellifera adansonii) in Africa. $X X X I I$ Int Congr Apicult, Rio de Janeiro, 77-78 